\title{
Representasi Femme Fatale dalam Novel Cantik Itu Luka Karya Eka Kurniawan
}

\author{
${ }^{1}$ Witakania S. Som - 2 Ferli Hasanah \\ 1Universitas Padjadjaran / Université de Poitiers - France \\ 2Universitas Padjadjaran - Indonésie \\ ${ }^{1}$ witakania.som@unpad.ac.id / sundasari.som@etu.univ-poitiers.fr \\ 2 ferli.hasanah@unpad.ac.id
}

\begin{abstract}
Abstrak
Penelitian ini bertujuan untuk memaparkan karakteristik-karakteristik femme Fatale yang terdapat dalam novel Cantik Itu Luka. Melalui tokoh-tokoh perempuan yang berbeda, ciri-ciri tersebut dapat ditemukan. Dengan menggunakan konsep femme fatale dari Yvonne Tasker dan Edwards, lima tokoh perempuan, yaitu Dewi Ayu, Alamanda, Adinda, Maya Dewi, dan Si Cantik dapat dikategorikan sebagai femme fatale. Citra ini diperkuat juga dengan membandingkan ciri-ciri tersebut pada citra tokoh perempuan yang berbudi luhur. Simpulan akhir mengungkapkan bahwa pada diri tokoh-tokoh perempuan tersebut terdapat ambiguitas antara protagonis dan antagonis, femme fatale dan perempuan berbudi luhur. Dengan demikian dapat dikatakan bahwa ada citra baru perempuan yang dibangun oleh dekonstruksi seksualitas pada novel ini.
\end{abstract}

Kata kunci : femme fatale, perempuan, seksualitas

\begin{abstract}
This study aims to describe the characteristics of femme Fatale contained in the novel Cantik Itu Luka. Through different female characters, these characteristics can be found. Using the femme fatale concept of Yvonne Tasker and Edwards, five female characters, Dewi Ayu, Alamanda, Adinda, Maya Dewi, and Si Cantik, can be categorized as femme fatale. This image is also strengthened by comparing such characteristics in the image of a virtuous woman. The final conclusion reveals that in the female characters there is and ambiguity between the protagonist and the antagonist, the femme fatale and the virtuous woman. Thus it can be said that there is a new image of women built by the deconstruction of sexuality in this novel
\end{abstract}

Keywods: femme fatale, woman, seksuality

\section{Pendahuluan}

Eka Kurniawan telah mempublikasikan empat novel, empat kumpulan cerpen dan satu essai selama karir penulisan gemilangnya. Karyakaryanya juga telah diterjemahkan ke dalam 24 bahasa asing. Salah satu maha karyanya adalah novel Cantik Itu Luka yang mendapatkan penghargaan luas dari masyarakat, media, dan kritikus sastra. Pada tahun 2016, novel ini memenangkan penghargaan World Reader's
Award dan Best Translated Book Award Fiction Longlist).

Dalam novel tersebut, pembaca dapat menemukan pencampuran berbagai unsur, seperti sejarah, dongeng, fantasi, tahayul, legenda, yang dibalut humor satir serta berlatarkan masa pendudukan Belanda, Jepang, masa kemerdekaan, hingga rezim Orde Baru. Untuk gaya humornya, Kurniawan seringkali dikaitkan dengan penulis Jepang seperti Haruki Murakami sedangkan 
adanya perpaduan berbagai unsur realis dan magis kerap dihubungkan dengan penulis Kolombia, Gabriel Garcia Márquez atau penulis British-India, Salman Rushdie (Smith: 2015).

Namun, bukan aspek realis-magis yang akan menjadi pembahasan kami dalam tulisan ini. Diawali dengan judul yang membandingkan kecantikan dengan luka atau penderitaan, kami tertarik dengan paradoks ini. Kami berasumsi bahwa ada tokoh-tokoh aneh (bizarre) yang berada di luar kebiasaan. Maka kami akan memaparkan tokoh-tokoh ciptaan Kurniawan tersebut yang dapat dikategorikan sebagai Femme Fatale.

Berbeda dengan konstruksi cerita tradisional yang mengasosiasikan kecantikan fisik pada tokoh protagonist yang memiliki kebaikan absolut, figur-figur perempuan dalam novel Cantik Itu Luka luar biasa cantik sekaligus mengerikan, bersifat liar, serta bertingkah laku kurang ajar, bahkan kejam dan sadis. Karakteristik-karakteristik itulah yang selanjutnya mengaburkan batasan protagonist dan antagonis.

Cantik Itu Luka bercerita tentang Dewi Ayu, seorang pelacur bereputasi di Halimunda, sebuah desa kecil di pinggiran pantai. Tanpa bersuami dan ada pernikahan, Dewi Ayu memiliki empat putri. Tiga putri yang pertama terlahir dengan kecantikan yang luar biasa. Sedangkan si Bungsu ditakdirkan berwajah buruk rupa. Diceritakan bahwa Dewi Ayu dan anak-anaknya yang cantik memporakporandakan kehidupan laki-laki di desa mereka. Seksualitas mereka menghancurkan hidup dan tidak jarang mengakibatkan penderitaan bagi para lelaki. Hal inilah yang membuat kami menghubungkan tokoh-tokoh tersebut pada karakteristik femme fatale.

Tema femme fatale bukanlah hal yang baru di dunia sastra. Pada abad ke-19 kita menjumpai Emma Bovary dalam karya pengarang Perancis, Gustave Flaubert, sebagai perempuan yang memesona tapi kecantikannya tidak hanya menghancurkan suaminya, Charles, tetapi juga hidup Léon Dupuis dan Rodolphe Boulanger. Sebuah kisah dari Tan Boen Kim dari kari karya sastra Indo yang diterbitkan pada tahun 1917, Si Riboet atawa Boenga Mengandoeng Ratjoen: Soeatoe Tjerita jang Betoel Terdjadi di Soerabaja Koetika di Pertengahan Taon 1916, jaitoe Politie Opziener Coenraad Boenoe Actrice Constantinopel jang Mendjadi Katjinta'annya (1917), menunjukkan bagaimana Si Riboet, seorang aktris cantik yang merayu Charles Coenrad dan membawa laki-laki tersebut ke dalam penderitaan hingga sang pria membunuh si perempuan (Chandra, 2011). Berdasarkan masa penulisan yang menempatkan karya sastra sebagai sarana untuk mendidik, tokoh-tokoh femme fatale ini dihukum dengan akhir kematian yang tragis.

Berbeda dengan Cantik Itu Luka, femme fatale direpresentasikan sebagai perempuanperempuan seksual yang cukup bahagia. Tulisan ini bertujuan untuk menunjukkan citra femme fatale berdasarkan karakteristik dan atribut feminine mereka serta tokoh-tokoh mana saja yang beroposisi dengan mereka, dengan perkataan lain tokoh-tokoh yang memiliki peran sebagai perempuan berbudi luhur. Dengan perbandingan ini, kami juga akan mengungkap potret 
Poetika : Jurnal Ilmu Sastra

Vol. V No. 1, Juli 2017

perempuan dalam konteks budaya Indonesia yang dikisahkan oleh Eka Kurniawan dalam novelnya.

Metode yang digunakan dalam analisis ini adalah metode deskriptif kualitiatif. Pertama, penelitian dimulai dengan menemukan tokohtokoh perempuan yang diindikasi sebagai femme fatale dan femme domestique (ibu rumah tangga) sebagai perempuan berbudi luhur. Adapun tokoh-tokoh yang dianalisis selanjutnya adalah :

(1) Dewi Ayu, (2) Alamanda, (3) Adinda, (4) Maya Dewi, (5) Si Cantik.

Setelah itu, analisis dilanjutkan dengan mengobservasi karakteristik tokoh-tokoh tersebut. Dengan menggunakan teori femme fatale dari Yvonne Tasker dan Edwards, kami menemukan bahwa stereotip femme fatale selain cantik, adalah perempuan penggoda, kasar, dan aggressif. Terakhir, akan ditunjukkan kontras dan ambiguitas karakter-karakter mereka dengan perempuan 'baik-baik'. Penggambaran ini pentung untuk mendapatkan gambaran perempuan dalam novel yang dianalisis.

\section{Permasalahan}

Seperti yang telah dijelaskan sebelumnya, kami akan membatasi analisis pada lima tokoh perempuan, yakni Dewi Ayu dan keempat putrinya. Definisi femme fatale sendiri akan disandarkan pada penjelasan dari Yvonne Tasker sebagaimana dibahas oleh Simkin (2014), sebagai berikut:

First, her seductive sexuality. Second, the power and strength (over men) that this sexuality generates for the fermme fatale. Third, the
DOI $10.22146 /$ poetika.25446 ISSN 2338-5383 (print) ; 2503-4642 (online)

deceptions, disguises and confusion that surrounds her, producing her as an ambiguous figure for both the audience and the hero. Fourth, as a consequence the sense of woman as 'enigma', typically located within an investigative narrative structure which seeks to find 'truth' amidst the deception. (18)

Berdasarkan penjelasan tersebut, kriteria pertama yang ditemukan pada femme fatale adalah seksualitas yang menggoda. Sifat ini ada pada penggambaran Eka Kurniawan saat menegaskan kecantikan fisik tokoh-tokoh perempuannya. Femme fatale adalah perempuan cantik dengan tubuh sempurna :

[...] seorang gadis muda yang begitu cantik, tampak tak peduli pada kenyataan babwa sebagian penonton adalab laki-laki. Umurnya mungkin baru enam belas tabun, seperti seorang bidadari tersesat. Rambutnya diikat dalam satu ikatan pita warna bijau tua, babkan dari kejauban Sang Shodancho bisa melihat mata mungilnya yang tajam, bidungnya yang mencuat, dan senyumnya yang terasa sangat kejam. Kulitnya putih seperti mengeluarkan cabaya, diselimuti gaun warna gading yang menawan di sore yang penub angin laut. Gadis itu mengeluarkan sigaret dari saku gaunnya, dan dengan ketenangan luar biasa ia merokok, [...]

Pemaparan tersebut memenuhi kriteria ideal feminin, sebagaimana kita ketahui, ditandai dengan detail mengenai wajah, rambut yang panjang (tidak pernah pendek), senyum yang 
Poetika : Jurnal Ilmu Sastra

Vol. V No. 1, Juli 2017
DOI 10.22146/poetika.25446 ISSN 2338-5383 (print) ; 2503-4642 (online)

"Tak ada seorang pun di kota ini, dan mungkin di seluruh alam semesta, lebih cantik. darinya. Ia lebih cantik daripada Rengganis Sang Putri yang kawin dengan anjing, paling tidak menurutku. Ia lebih cantik dari Ratu Laut Kidul. Ia lebih cantik daripada Helena yang membuat perang Troya meletus. Ia lebih cantik. dari Diab Pitaloka yang menyebabkan perang Majapabit dan Pajajaran. Ia lebih cantik daripada Juliet yang membuat Romeo nekat bunub diri. Ia lebih cantik dari siapa pun. selurub tububnya seperti mengeluarkan cahaya, rambutnya lebih mengilau dari sepatu yang baru disemir, wajahnya begitu lembut seolab ia dibuat dari lilin, dan senyumnya seperti mengisap segala yang ada di sekitarnya. (165)

Dua kutipan di atas menjelaskan kecantikan Almanda, seorang perempuan muda dengan sebuah aura, katakanlah, mistis, tetapi juga sekaligus modern dari caranya berpakaian dan dari kebiasaannya menghisap rokok. Meskipun demikian, kecantikan bukanlah hanya milik Alamanda seorang, kita juga dapat temukan kecantikan ini pada diri Dewi Ayu dan dua anaknya yang lain, Adinda dan Maya Dewi. Hanya saja, berbeda dengan Alamanda dengan sisi modernitasnya, Adinda, adiknya, merepresentasikan sosok perempuan muda tradisional dengan tatanan rambutnya yang sederhana juga bersifat naif sebagai seorang gadis muda.

[...] satu kecantikan yang unik, satu kecantikan para putri dan bidadari yang lembut dan mistis, tradisional, kuno, alami, dengan 
Poetika : Jurnal Ilmu Sastra

Vol. V No. 1, Juli 2017
DOI 10.22146/poetika.25446

ISSN 2338-5383 (print) ; 2503-4642 (online) rambut dikepang dua, dengan mata yang terpejam itu dibiasi bulu mata lentik, dengan bidung mencuat ramping berbiaskan dan cuping bagai dipabat demikian halus, dengan bibir yang merengut kecil, dengan pipi berisi, [...] (271)

Eka menunjukkan kecantikan Maya Dewi dengan sedikit sensualitas melalui tubuh remaja yang muda.

\section{[...] ia sunggub-sungguh demikian} cantik, warisan kecantikan ibunya, dengan rambut mengembang di atas bantal, dengan buah dada mencuat terang-gelap di bawah temaram lampu, [...] Pinggulnya begitu indah dan kuat, $[. .$.$] (325)$

Sementara itu, ibu mereka, Dewi Ayu, menampilkan kecantikan dan keanggunan sekaligus sensualitas seorang perempuan matang.

Di bawah cahaya lampu, kulitnya sangat bersih, menandai warisan yang nyata orang-orang Belanda. Ia Peranakan campuran, dengan mata agak kebiruan. Rambutnya bitam gelap, disanggul memanjang seperti sanggul perempuan-perempuan Perancis. Ia masih merokok, dengan sigaret yang diapit jari -jemari ramping panjang, kuku-kukunya dikutek merah darah. Dewi Ayu mengenakan gaun warna gading dengan tali mengikat pinggangnya yang ramping. Ia mendengar apa yang dikatakan lelaki itu pada Mama Kalong, lalu ia mendongak menoleh padanya. Sejenak mereka saling memandang dan Dewi Ayu tersenyum menggoda tanpa beranjak. "Segeralah, Sayang, sebelum kau mengompol di celana, "katanya. (120)
Tokoh Dewi Ayu ini, menggunakan semua kelebihan fisiknya untuk memikat laki-laki, tanpa terjatuh pada sifat kasar dan vulgar. Dengan demikian dapat dikatakan bahwa Dewi Ayu bukanlah pelacur sembarangan, ia memiliki kelasnya tersendiri. Di sisi lain, putrinya lah, anak sekolahan, yang memenuhi karakteristik perempuan murahan yang menggoda laki-laki dengan gaya busananya yang seksi. «menggodanya dengan leher gaun yang sedikit terbuka» (192). Dengan sifat centil, Alamanda menghipnotis mangsanya dengan gerak-geriknya, senyumnya, dan pandangannya yang menantang. Dengan sadar ia menggunakan kecantikan, seksualitas, dan femininitas sebagai senjatanya.

Alamanda telab berbubungan dengan banyak lelaki sebelum mencampakkan mereka satu per satu. Itu reputasi buruknya, dan semua orang mengetahuinya termasuk Adinda. Ia melakukan semua ini pada beberapa teman sekolahnya, sedikit memprovokasi dengan kecantikannya, senyum yang memikat, lirikan genit, langkah yang gemulai, hal-hal seperti itu bisa membuat banyak teman laki-lakinya terserang insomnia mendadak. Tak taban dengan insomnia tanpa harapan penyembuban, beberapa anak laki-laki akan mencoba memburunya dan ia akan mulai berubah menjadi merpati jinak, yang melompat-lompat setiap kali hendake ditangkap. (188)

Selanjutnya, dalam konteks masyarakat Indonesia, keperawanan pada perempuan secara ketat dianggap sebagai sesuatu yang sakral dan diasosiasikan dengan kehormatan, tidak hanya bagi perempuan itu sendiri tapi kehormatan 
Poetika : Jurnal Ilmu Sastra

Vol. V No. 1, Juli 2017
DOI $10.22146 /$ poetika.25446

ISSN 2338-5383 (print) ; 2503-4642 (online)

sikap eksklusifnya, Mama Kalong memberi tarif mahal bagi siapa pun yang menginginkan tububnya. (104)

Meskipun tubuhnya dijual, Dewi Ayu menunjukkan citra dari "perempuan baik-baik»» dengan caranya berpakaian. Tentu saja, pakaian tidak selalu merepresentasikan kepribadian seseorang, tetapi melalui pakaiannya, Dewi Ayu menunjukkan kelas dan seleranya yang membuat perempuan-perempuan lain ingin mengikuti gayanya.

\section{[...] berpakaian babkan jauh lebih} Halimunda tapi kau tak man memerkosa kekasibmu sendiri?"

"Sebab kau berbeda" [...] "sampai kita kawin," (199)

Dengan demikian, Alamanda menunjukkan seksualitasnya yang aktif dan agressif, sejalan dengan perkataan ibunya, Dewi Ayu « aku melabirkan gadis-gadis pemburu kemaluan laki-laki» (249).

Bersebrangan dengan tokoh penggoda, kasar, dan vulgar, Kurniawan mengindikasikan bahwa prostitusi sebenarnya adalah profesi yang bisa dijalani dengan kehormatan dan atas pilihan pribadi. Melalui Dewi Ayu kita melihat ekslusifitas pada pekerjaan yang pada umumnya selalu direndahkan

Tak seorang pun memperlakukannya secara kasar sebagaimana biasa mereka lakukan pada pelacur lain [...] Tak pernah semalam pn ia tak memperoleh tamu, meskipun ia sangat membatasi hanya tidur dengan seorang lelaki dalam semalam. Untuk. sopan daripada perempuan-perempuan saleh mana pun. [...] Sementara Dewi Ayu menyukai gaun-gaun bermotif, yang dipesan dari seorang penjabit langganan, yang menjiplaknya persis dari halaman mode majalah perempuan. Babkan perempuan-perempuan saleh secara diam-diam banyak belajar kepadanya bagaimana merawat tubuh dan berpakaian. (105)

Untuk memperkuat citra ini, Kurniawan menggambarkan Dewi Ayu sebagai ibu yang baik karena putri-putrinya menempati bagian besar dalam hidupnya. Ia adalah seorang ibu teladan.

Jika malam hari, anak-anak itu ditemani oleh Mirah, namun di siang hari ia mengurus anak-anak itu sebagaimana seorang ibu umumnya. Ia mengirimkan anak-anak itu ke sekolah terbaik, babkan mengirimkannya pula ke surau untuk belajar mengaji pada Kyai Jabro.

Dari data-data tersebut kami dapat menyimpulkan bahwa Dewi Ayu adalah pelacur 
Poetika : Jurnal Ilmu Sastra

Vol. V No. 1, Juli 2017

tapi juga seorang ibu, seorang pendosa sekaligus teladan. Laki-laki mengaguminya dan memimpikannya. Kecantikan, tubuh, dan seksualitasnya membuat mereka terobsesi. Dengan demikian, pengarang menciptakan sosok pelacur bermartabat.

Untuk membahas femme fatale, Simkin menjelaskan bahwa «the image of the disobedient woman is also frequently set against her polar opposite : configurations of the maternal, the chaste and the virginali (2014 : 5-6). Bertemu dengan citra femme fatale, Kurniawan menghadirkan juga citra perempuan berbudi luhur, yaitu perempuan «qui manifeste de la vertu, des qualités morales [...] qui est inspiré par de nobles sentiments» (yang memiliki kebajikan, kualitas moral [...] yang terinspirasi dari perasaan bangsawan) (www. larousse.fr), Maka perempuan berbudi luhur wajib memiliki kesucian, kebijaksanaan, loyalitas. Karakter-karakter ini adalah tiang utama pernikahan dan kehidupan berumah tangga. Dalam konteks masyarakat Indonesia, hanya dalam konteks pernikahanlah pasangan dapat secara legal menunjukkan seksualitanya. Oleh karena itu, «Dewi Ayu berpikir untuk. mengawinkan Maya Dewi secepatnya, sebelum ia tumbuh dan menjadi binal» (250).

Kemudian kita disuguhi oleh stereotip ibu rumah tangga yang direpresentasikan oleh Maya Dewi yang menghabiskan waktunya untuk mengurusi rumah tangga.

Tak lama setelab itu ia baru menyadari bakat luar biasa istrinya sebagai ibu rumah tangga. Ia tak hanya menyediakan
DOI $10.22146 /$ poetika.25446 ISSN 2338-5383 (print) ; 2503-4642 (online)

pakaian-pakaian yang rapi tersetrika dan babkan wangi untuk ia kenakan, ia babkan memasak semua masakan yang ia makan dan ia rasakan begitu nikmat di lidah. (265)

Karena masih dianggap anak-anak, Maya Dewi menjadi istri yang tidak dapat disentuh oleh Maman Gendeng, suaminya. Di hadapan kepolosan anak-anak, Maman Gendeng menahan secara sukarela hasrat seksualnya.

Demikianlah Maman Gendeng begitu bangga pada kesabaran hatinya, bertabun-tabun tak bercinta dengan perempuan mana pun kecuali dengan tangannya sendiri di kamar mandi, sekitar sekali seminggu pada hari-hari yang tak tertahankan, atau sebulan sekali pada hari-hari yang penub pertabanan diri. Sentuban pada istrinya mungkin hanya sebatas ciuman di dabi menjelang ia tidur atau saat ia akan pergi ke sekolah, kadang-kadang duduk saling berpelukan waktu mereka menonton di bioskop. Dan membopongnya ke tempat tidur jikea istrinya tertidur di sofa. Babkan ia belum pernah melihatnya telanjang bulat. (324)

hingga hari saat Maya Dewi mengajaknya ke tempat tidur sambil mengatakan bahwa ia saat itu adalah seorang istri yang telah menyadari seksualitasnya.

"Sayang, aku adalah istrimu dan aku sudah cukup dewasa untuk menerimamu di atas tempat tidur," katanya sebelum melanjutkan, "peluk dan bercintalah denganku mala mini, sebab ini malam terindah yang akan kita miliki, 
Poetika : Jurnal Ilmu Sastra

Vol. V No. 1, Juli 2017
DOI 10.22146/poetika.25446

ISSN 2338-5383 (print) ; 2503-4642 (online) malam pertama setelah lima tabun terlambat.” (325)

dari kutipan tersebut dapat diketahui bahwa Dewi Ayu lah yang mengambil inisiatif. Setelah itu, kemudian mereka menjalani kehidupan seksual yang aktif.

\section{Mereka larut dalam malam pertama} yang meriah dan nyaris tanpa akbir, berlalu bingga berminggu-minggu setelah itu. Mereka nyaris tak pernah keluar rumah bagaikan pengantin baru sesunggubnya, bercinta dari senja sampai pagi dan dari pagi sampai senja. Hanya keluar kamar untuk makan dan minum dan ke kamar mandi dan menghirup udara segar sebelum kembali ke tempat tidur.

Di sisi lain, Alamanda, meskipun memiliki sifat penggoda, ia menolak hubungan seksual dengan alasan balas dendam dan kemarahan terhadap suaminya sehingga ia melindungi diri dengan memakai celana dalam besi yang dilindungi oleh mantra, dan hanya ia sendiri yang dapat membukanya.

"Kita sudah berjanji Shodancho," " kata Alamanda lagi, "babwa kau bisa mengawini aku tapi aku tak akan bercinta denganmu.” (221)

Alamanda membiarkan suaminya dalam frustasi seksual yang berkepanjangan. Sejalan dengan karakteristik femme fatale yang menganggap seksualitas adalah «the association of erotisme with pain and death and the belief that sexual relations entail a subjugation, often violent and destructive» (Bade, 1979 : 7).

Satu-satunya yang bisa dilakukan Sang Shodancho sekarang adalab menyerah pada nasib untuk tak pernah merasakan rasanya bercinta dengan perempuan, kecuali kesempatankesempatan darurat bercinta dengan bantal dan guling di atas tempat tidur. Sementara di lain waktu ketika ia tak tahan dengan segala permainan gila tersebut, ia akan lari tergopohgopoh masuk kamar mandi dan membuang isi buah pelirnya ke dalam lubang kakus. (223)

Tetapi, di akhir cerita, kita dapat menyaksikan kehidupan seksual mereka yang pada akhirnya aktif, bahkan liar.

Mereka bercinta malam itu dengan begitu liar dan dahsyat, bermula di atas tempat tidur warna kuning tersebut, lalu bergeser ke lantai saat mereka terguling tanpa sadar, lalu berlanjut di kamar mandi. Dan melakukannya di sofa pada saat matahari telab menyorot tajam.

Mereka menutup semua pintu rumah, mengurung para pembantu di dapur, dan melakukannya lagi di ruang tamu diselingi membaca buku-buku porno, kembali lagi ke kamar mandi, dan semuanya dilakukan dalam kejutan-kejutan untuk tetangga dan para pembantu yang bertanya -tanya di dapur karena teriakan-teriakan pendek Alamanda serta dengusan Sang Shodancho.

Mereka melakukannya hingga tiga kali ejakulasi di malam sempit itu, tapi memuaskannya menjadi sebelas kali sepanjang siang: sungguh-sungguh sepasang petarung yang telah dibuat lapar selama lima tabun. (330) 
Poetika : Jurnal Ilmu Sastra

Vol. V No. 1, Juli 2017

Selanjutnya, dari sisi konsepsi femme fatale, kita mengetahui «the monstrous-feminine, by contrast, consist of those women whose horrific crimes are matched of their moral and, usually, their physical deviations from standard notion of beauty » (Simkin, 2014 : 8). Berkaitan dengan definisi ini, Kurniawan menciptakan sebuah paradox ganda melalui tokoh Si Cantik. Pertama, nama Si Cantik diberikan pada seorang tokoh yang penampilah fisiknya tidak ada hubungannya sama sekali dengan kecantikan. Kedua, secara fisik, Si Cantik begitu buruk rupa, tetapi tidak secara moral. Ia berperilaku baik. Ia menunjukkan bahwa ia sangat berbakat. Satusatunya kejahatan Si Cantik yang menakutkan penduduk desa Halimunda adalah fisiknya yang mengerikan seperti monster.

Ia gadis buruk rupa dengan lubang bidung menyerupai colokan listrik dan kulit hitam legam seperti jelaga. Ia gadis yang menakutkan, yang akan membuat orang mual dan muntah-muntah, membuat orang tidak sadarkan diri dalam teror, membuat orang kencing di celana, membuat orang lari kesetanan, dan tidak membuat orang jatuh cinta (464)

Tetapi, dalam novel Kurniawan, kecantikan atau kejelekan fisik hanyalah masalah sudut pandang, masalah selera. Maka selera, sebagaimana selera terhadap warna, bukalah hal yang bisa dipertanyakan. Begitu pula bagi tokoh Si Cantik, yang bagi tokoh Krisan adalah perempuan yang menarik.
DOI $10.22146 /$ poetika.25446 ISSN 2338-5383 (print) ; 2503-4642 (online)

Selama bertabun-tabun, Krisan memikirkan terus ide itu, tentang memiliki kekasih yang buruk rupa." Apa yang salah dengan perempuan yang buruk rupa?" katanya pada diri sendiri, "Mereka bisa dientot sebagaimana perempuan cantik." Dan ia teringat pada desas-desus tentang anak. Dewi Ayu yang konon buruk rupa, mungkin yang paling menakutkan di muka bumi, dan meskipun ia tahu bahwa Dewi Ayu adalah neneknya, dan itu berarti si buruk rupa yang konon bernama Si Cantik itu bibinya, ia tak peduli. Ia pernah menyetububi sepupunya sendiri, apa salabnya menyetububi bibi sendiri. (477)

Dengan demikian, meskipun Buruk rupa, Si Cantik dapat membangunkan hasrat seksual seorang laki-laki. Untuk itu, pengarang telah menolak anggapan bahwa buruknya rupa menyebabkan penolakan orang lain, bahwa kejelekan fisik tidak akan berterima, terutama dalam urusan seksualitas.

Mereka bercinta setiap kali bertemu, kadang-kadang sampai dua kali, dan merasa sebagai pasangan paling babagia di dunia. (470)

Masing-masing tokoh memiliki pesona dan seksualitanya sendiri. Tetapi kita bisa mengakui bahwa lima tokoh ini memiliki seksualitas yang kuat yang membawa mereka pada dua kriteria: pertama kekuatan dan kuasa, yang dengan keduanya femme fatale memainkan perananan sebagai pemegang kendali. Bagi pria yang menjadi korban, hanya penderitaan lah yang mereka alami. Ini adalah permainan yang mudah di mana femme fatale selalu menjadi pemenangnya. 
Poetika : Jurnal Ilmu Sastra

Vol. V No. 1, Juli 2017

Itu adalah saat terbaik untuk mengempaskan mereka, memporakporandakan hati mereka, menghancurkan seorang laki-laki, satu kesempatan memperlihatkan superioritas perempuan, sehingga Alamanda akan berkata, laki-laki, aku tak mencintaimu.

"Aku menyukai laki-laki, kata

Alamanda suatu ketika, "tapi aku lebih suka melihat mereka menangis karena cinta." (188)

Lebih lanjut Simkin sejalan dengan konvensi yang ada bahwa femme fatale adalah: «a beautiful woman who lures the male into dangerous situation by overpowering his will with her irresistible sexuality (2014: 8). Maka tidak ada laki-laki yang dapat menolak kecantikan perempuan tersebut. Seperti Sang Sodancho yang jatuh pada perangkap pesona Alamanda :

[...] Alamanda pergi meninggalkannya begitu saja tanpa pamit. Itu membuat Sang

Shodancho berdiri terpaku tak percaya.

Serangan gila itu bagaimanapun jauh lebih

mengerikan dari semua pertempuran yang

pernab dialaminya. Ia berbalik dan melangkah dengan tubuh dan jiwa yang sunggub tak berdaya.

"Adakah strategi gerilya untuk mengalabkan cinta?" tanyanya dalam satu keluban pendek pada diri sendiri. (157)

Siapa yang akan mengatakan tidak pada kecantikan seperti Alamanda bahkan Don Juan, Kamerad Kliwon menyerah secara dramatis pada pesona Alamanda.

Si kecil yang cantik itu telah menghancurkan segala-galanya, termasuk harihari dan mungkin masa depannya. Dalam beberapa hari setelah pertemuan singkat itu, segalanya tiba-tiba menjadi berubah. Ia
DOI 10.22146/poetika.25446 ISSN 2338-5383 (print) ; 2503-4642 (online)

mengusir semua gadis yang mencoba mendekatinya, menolak semua ajakan peseta, dan lebih banyak tinggal di rumah merenungi nasib cintanya yang tampak menyedibkan : seorang penakluk gadis-gadis dibuat tak berdaya [...] (164)

Cinta dan hasrat telah melemahkannya, tidak hanya secara psikis, tetapi juga fisik.

Gadis itu telah sungguh-sungguh menjadi terror baginya, jauh lebih membuatnya menggigil daripada seandainya ia bertemu setan dedemit. Di malam hari ia memimpikannya bagaikan mimpi buruk, sebab Kliwon akan terbangun secara tibatiba dengan tubub kaku, keringat bercucuran dan napas tersengal-sengal. [...] Kliwon sunggubsungguh tak tahan menghadapi kenyataan bahwa bidupannya akan dihabiskan hanya dengan cara seperti itu. Suatu hari akbirnya ia ambruk dalam demam, [...] (167)

Kita dapat katakan bahwa seksualitas yang sangat kuat dari femme fatale "'leads men into difficult, dangerous, or disastrous situations.' What is more difficult, dangerous, or (potentially) disastrous than growing up» (Edwards: 43). Selanjutnya, Eka menggambarkan bagaimana ketertarikan seksual bersifat destruktif dan membawa laki-laki pada penderitaan, ketidakberdayaan, dan kekecewaan

Ia melamunkan gadis itu, kecantikannya, tububnya, dan ia terperosok ke dalam berabi yang meledak-ledak dalam ketidaksabaran sebingga tangannya bergerak kembali meraih fotofoto tersebut, melibatnya kembali berganti-ganti, mengelus permukaan kertasnya bagaikan itu adalab tubuh si gadis dan ia semakin larut dalam berabi anjing di musim kawin, matanya mulai memandang dalam kemesuman dan ia berbalik 
Poetika : Jurnal Ilmu Sastra

Vol. V No. 1, Juli 2017

tertelungkup meletakekan foto-foto itu di atas bantal, menelusurinya dengan jari-jari telunjuk dan bibirnya mulai menggumamkan nama gadis tersebut. [...]

Sang Shondancho bertanya, "Di mana ada pelacuran di kota ini?” (205)

Seperti yang diungkapkan Place bahwa "The dark lady, the spider woman, the evil seductress who tempts man and brings about his destruction» (1998: 47). Kita temukan bahwa femme fatale adalah pengejawantahan dari Pandora dan Medusa karena keindahan menggairahkan mereka mengusung penderitaan, kemalangan, atau kematian.

Tetapi, tokoh-tokoh feminin dalam novel ini digambarkan membawa kebaikan. Pekerjaan Dewi Ayu contohnya, «Kurang lebih selurub lelaki dewasa pernah menidurinya selama rentang waktu karirnya » (123), juga untuk Maman Gendeng, Dewi Ayu mengembalikan kebahagiaan dan menyelamatkannya dari derita cinta:

Untuk pertama kalinya, ia bisa melupakan semua luka-luka sebelumnya, melupakan Nasiah dan Rengganis Sang Putri, dan terpesona pada seorang pelacur yang begitu mengagumkan. (126)

dan setelah pernikahannya, Maya Dewi memotivasi Maman Gendeng untuk menjadi laki-laki yang baik.

"Aku datang hanya untuk mengatakan bahwa aku tak akan lagi menyentubmu." Itu baru mengejutkan Dewi Ayu, dan ia bertanya, "Kenapa?" "Dengan memiliki istri seperti anak
DOI $10.22146 /$ poetika.25446 ISSN 2338-5383 (print) ; 2503-4642 (online)

perempuanmu, aku tidak ingin menyentub perempuan mana pun lagi.” (266)

Selanjutnya, saat Alamanda menerima Sang Sodancho, Sodancho menemukan kehormatannya. tidak ada lagi yang meragukan kejantanannya, atau pun seksualitasnya. Selanjutnya, setelah kehidupan yang berliku, kehadiran Adinda memberikan kehidupan yang sederhana dan harmonis bagi Kamerad Kliwon. Bahkan Si Cantik, menawarkan kebahagiaan mendalam bagi pasangannya.

Melalui paparan di atas, kita menemukan tokoh-tokoh perempuan yang menunjukkan ketidakpastian. Dalam beberapa kasus, femme fatale membawa seseorang pada kekecewaan. Kita berbicara tentang kriteria yang ketiga yaitu kekecewaan, ketidakjelasan dan kebingungan yang melingkari sosok femme fatale yang kita lihat sebagai sosok yang ambigu. Tapi kita juga melihat sosok mereka tidak sepenuhnya gelap, ada kebaikan tersendiri dalam tokoh-tokoh tersebut.

Maka dari itu, apakah Dewi Ayu merupakan seorang kekasih yang sedang jatuh cinta atau hanya seorang pelacur yang berperan baik? Ia begitu cantik dan memikat dan memiliki jiwa yang bebas. Mampukah Alamanda menahan diri dari kenikmatan seksual selama bertahuntahun? Apakah Adinda menerima Kamerad Kliwon dikarenakan cinta atau rasa kasihan? atau karena cemburu pada Alamanda? Bagaimana Maya Dewi tetap mejadi gadis polos sekaligus pengoda bagi Maman Gendeng? Si Cantik yang sama sekali tidak cantik, apakah ia merepresentasikan monster? tetapi bagaimana menjelaskan seksualitas Si Cantik yang menarik hati seorang laki-laki?. 
Masing-masing tokoh menunjukkan karakteristik mereka tersendiri. Seperti malaikat yang menyamar sebagai iblis. Mereka menunjukkan ambiguitas. Bagi Doane sebagaimana dibahas Hanson dan O'Rawe «For her most striking characteristic, perhaps, is the fact that she never really is what she seems to be »(1991: 1). Dengan demikian, kami tidak bisa mengatakan tokoh ini adalah femme fatale atau tokoh itu adalah perempuan berbudi luhur. Kami bisa katakan bahwa mereka setengah Maria (Madone) setengah pelacur, atau setengah malaikat dan setengah iblis, setengah patuh dan setengah pemberontak. Dengan adanya kriteria yang keempat, maka femme fatale tetap menjadi sebuah teka-teki dengan berbagai misterinya. Kurniawan meninggalkan pertanyaan yang mungkin tidak akan berani kita jawab: apakah semua perempuan memang pelacur?

"Seorang pelacur bercinta karena uang, apa yang akan kita sebut pada seorang perempuan yang kawin juga karena uang dan status sosial? Ia lebih dari seorang pelacur, ia dewi pelacur." (234)

\section{Kesimpulan}

kami dapat menunjukkan bahwa tokohtokoh yang dianalisis merepresentasikan beberapa karakteristik yang dapat kita namakan sebagai femme fatale. Meskipun demikian, tokohtokoh tersebut menunjukkan kesesuaian dengan ciri-ciri sebaliknya. Semua tokoh digambarkan sebagai sosok setengah femme fatale dan setengah perempuan berbudi luhur. Bedasarkan penjelasan tersebut kami bisa tegaskan argumentasi kami bahwa pengarang telah mengaburkan batasan antara kebaikan dan kejahatan, antara protagonist dan antagonis. Dengan demikian, novel ini menawarkan sebuah definisi baru dengan karakteristik-karakteristik khusus mengenai femme fatale dalam konteks budaya Indonesia dan Eka Kurniawan mengajukan konsep miliknya melalui tokoh-tokoh tersebut.

\section{Daftar Pustaka}

Bade, Patrick. (1979). Femme Fatale : Images of Evil and Fascinating Women. New York : Mayflower Books.

Chandra, Elizabeth. Women and Modernity : Reading the Femme Fatale in Early Twentieth-Century Indies Novels. Dans Indonesia, No. 92. (2011), 157-182. Repéré à http://www.jstor.org/stable/10.5728/ indonesia.92.0157

Edwards, Karen L. The Mothers of All Femmes Fatales: Eve as Temptress in Genesis 3. Dans Hanson, Helen et O'Rawe, Catherine (éd), (2010). The Femme Fatale : Images, Histories, Contexts. New York : Palgrave Macmillan.

Hanson, Helen et O'Rawe, Catherine.. Introduction: 'Cherchez la femme'. Dans Hanson, Helen et O'Rawe, Catherine (éd), (2010). The Femme Fatale : Images, Histories, Contexts. 16-23. New York: Palgrave Macmillan

Kurniawan, Eka. (2016). Cantik Itu Luka.Jakarta : Gramedia Pustaka Utama.

Simkin, Stevie. (2014). Cultural Constructions of the Femme Fatale: From Pandora's Box to Amanda Knox. London : Palgrave Macmillan.

DICTIONNAIRES DE FRANÇAIS. (n.d.). Retrieved from http://www.larousse.fr/

Deborah, S. (2015). Man Tiger by Eka Kurniawan review. Retrieved from https:// www.theguardian.com/books/2015/ nov/28/man-tiger-eka-kurniawan-reviewcrime-novel-indonesian. 